Área Abierta. Revista de comunicación

audiovisual y publicitaria

ISSN: 1578-8393 / ISSNe: 1578-8393

\title{
Orígenes, evolución y crisis del sistema de exhibición cinematográfica en el Teatro Principal de Zamora: 1897-1984
}

\author{
Fco. Javier Alcina Rodríguez-San León ${ }^{1}$ \\ Recibido: 12 de marzo de 2018 / Aceptado: 3 de abril de 2018
}

Resumen. Este artículo es un resumen de una investigación sobre la situación de la exhibición cinematográfica en el Teatro Principal de Zamora durante sus años de existencia como sala de cine. Desde la etapa finisecular del XIX, a su cierre en los años ochenta del pasado siglo, este coliseo pasaría por varios propietarios y regentes, fue testigo de la mayoría de edad del séptimo arte, de la conversión al sonoro, así como la proyección de cintas en Technicolor y Cinemascope. Pero sobre todo - este coliseo- fue la cabeza visible de la crisis del sistema de exhibición en la capital del Duero - ya que tras él - se desmoronarían el resto de las míticas salas de la ciudad.

Palabras clave: Exhibición, Cinematógrafo, Teatro Principal, Zamora, Cine Español, Crisis.

\section{[en] Origin, Evolution and Crisis of the Cinematographic Display's System at the Teatro Principal in Zamora 1897-1984}

\begin{abstract}
This article is a overview of an investigation about the situation of the cinamatographic display at the Teatro Principal in Zamora during its years as a cinema. From the turn-of-the-century period of the XIX century to its closure in the eighties, this coliseum has had many owners and regents; it was a witness of the age of majority, the change to sound, even so the proyection of tapes in Technicolor and Cinemascope. Above all-this coliseum-it was the visible head of the crisis of the cinamatographic display in the Duero's capital-after him-all the other cinemas around the city would crumble down.
\end{abstract}

Keywords: Display, Cinematograhic, Teatro Principal, Zamora, Spanish Cinema, Crisis.

Sumario. 1. Introducción. 2. Metodología. 3. Los orígenes del teatro como exhibidor cinematográfico. 4. Cinematógrafo y varietés. 5. Crisis de exhibición en Europa. 6. La transición al cine sonoro. 7. El monopolio de la exhibición. 8. La etapa franquista. 9. La decadencia del coliseo. 10. Conclusiones. 11. Bibliografía. 12. Archivos. 13. Agradecimientos

Cómo citar: Alcina, J. (2018). Orígenes, evolución y crisis del sistema de exhibición cinematográfica en el Teatro Principal de Zamora: 1897-1984. En Área Abierta. Revista de comunicación audiovisual y publicitaria. 18 (2), 341-362. http://dx.doi.org/10.5209/ARAB.59507

1 Universidad Jaume I, Castellón (España)

E-mail: falcina@ucm.es 


\section{Introducción}

Durante los años cincuenta y sesenta del pasado siglo, la exhibición cinematográfica atravesaba por una gran dificultad, debido a los altos porcentajes que las distribuidoras imponían a los empresarios de las salas por localidades vendidas.

Desde que en 1897 el cinematógrafo se presentara en este coliseo, han sido innumerables las proyecciones realizadas durante el siglo xx. La importancia del Teatro Principal como medio de distracción — primero de la gente más pudiente y más tarde del resto de clases sociales - ha definido a este espacio como el lugar donde más exhibiciones se realizaron la pasada centuria en la ciudad castellana. A lo largo de su actividad, el local fue testigo de los primeros cinematógrafos ambulantes, su representación junto a los números de variedades, de la edad de oro de la época muda, de la transición al cine sonoro y de la competencia con el Nuevo Teatro. Más tarde, el Principal rivalizaría con las primeras salas dedicadas hasta su decadencia en los años setenta y su posterior cierre, una década más tarde. Durante la pasada centuria el Principal fue regentado por numerosos empresarios, aunque su máximo impulsor sería Alejandro Sanvicente, quien desde la etapa que engloba los años veinte a sesenta aprovecharía su presidencia en la asociación de empresarios de espectáculos de España para conseguir los mejores contratos con las distribuidoras más importantes del país. Con su fallecimiento también se esfumaría una parte importante de la exhibición cinematográfica en Zamora, ya que sus competidores no estuvieron a la altura del carismático empresario.

Existen datos fiables que muestran la pérdida de la afición al cine por parte de los zamoranos. Son datos extrapolables a cualquier ciudad de provincias de España, ya que buena parte del declive de las salas comerciales fue la cada vez más presencia con la que contaba la televisión y el vídeo en los hogares, convirtiendo al séptimo arte en un producto de lujo, tal y como le sucedió a finales del siglo XX con las primeras proyecciones. Las seis salas ${ }^{2}$ que poseía Zamora en 1983 fueron desapareciendo durante esa década, dejando paso a las nuevas multisalas a principios de los noventa.

Se trata, por tanto, de establecer una visión panorámica de la sala que más actividad cinematográfica ha tenido durante el pasado siglo. En este artículo se exponen y presentan conclusiones de investigación sobre las causas que generaron el fin de la actividad cinematográfica en el Teatro Principal, centrando el objeto de estudio en su trayectoria histórica.

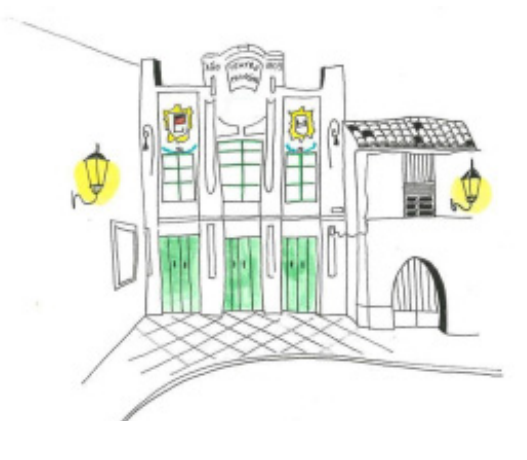

Figura 1. Ilustración del Teatro Principal. (2018). Autora: Romina Boaventura para esta investigación

2 Las seis salas eran los dos teatros, el Cine Barrueco, Cine Pompeya (antiguo Valderrey), Cinema Arias Gonzalo y Cine Cervantes (antiguos Luises). 


\section{Metodología}

El trabajo que se presenta es fruto de una investigación multidisciplinar sobre la historia del Teatro Principal de Zamora y su importancia como local de exhibición cinematográfica durante el siglo xx. Para realizar esta investigación se ha abordado, por tanto, una metodología que engloba áreas y disciplinas de las ciencias sociales, económicas y artísticas.

Teniendo en cuenta estos antecedentes, en el presente texto se analiza la evolución que ha tenido este espacio en la exhibición cinematográfica durante la pasada centuria. Por otro parte, se puede afirmar que el Teatro Principal de Zamora fue el lugar más emblemático de exhibición cinematográfica durante la pasada centuria.

En primer lugar, se ha realizado un vaciado a través de la prensa local, utilizando el Heraldo y El Correo de Zamora como fuentes primarias de nuestra investigación. Con los datos recopilatorios hallados en los Anuarios cinematográficos se han establecido comparaciones con las informaciones locales. También la documentación encontrada en el Archivo Histórico Provincial de Zamora en las secciones de Hacienda y de Vivienda, ha servido para recopilar datos sobre el precio de las localidades a través del pago de impuestos. Por último, se ha realizado una búsqueda por la Biblioteca Nacional, el Archivo General de la Administración — sobre la censura-, la Filmoteca de Castilla y León; y la Biblioteca de la Facultad de Ciencias de la Información de la Universidad Complutense de Madrid. Son de destacar las diferentes obras e investigaciones sobre la historia del cinematógrafo - tanto a nivel nacional como local- sirviendo de comparación por este trabajo.

Además, esta investigación se sustenta con dos metodologías - cuantitativas y cualitativas - . Las primeras — basadas en datos estadísticos y económicoshan servido como referencia para establecer el número de salas, sus precios y características. Por otro lado, se ha recurrido a las metodologías cualitativas, para comparar la exhibición cinematográfica del Teatro Principal con el resto de salas de proyección en la ciudad. Incluso se realizaron entrevistas a familiares y antiguos trabajadores de la empresa del coliseo.

Finalmente, los objetivos de este trabajo se centran en ofrecer un panorama de las proyecciones de películas acelebradas en el coliseo zamorano durante la centuria anterior. La hipótesis inicial o de partida de la investigación es que la crisis del sector de la exhibición en Zamora comenzaría con la decadencia del Teatro Principal. Por lo que la sala se convertirá en precedente de lo que, años más tarde, sucedería con el resto de cines.

\section{Los orígenes del teatro como exhibidor cinematográfico}

Se tienen datos de que ya a finales del siglo XIv, el lugar que ocuparía el primitivo Patio de Comedias era el Monasterio de Santa Paula y que este fue adquirido por Andrés Vázquez Miranda a las monjas de esa comunidad religiosa. Así lo describe Concha $\mathrm{M}^{\mathrm{a}}$ Ventura (1998: 5-31), que además narra como el nuevo propietario adquiere el edificio para su hermano Francisco, el cual realizaría la primera reunión de caballeros regidores en el ya construido patio de comedias en 1606. En el recinto cubierto se contemplaron varios cambios en su estructura durante los siglos XVI y XVII, llegando incluso a casi desaparecer. Su gran remodelación se produciría en 
el XIX gracias a la inclusión de una salida de humos en el cielo raso, la creación de tres órdenes de palcos, así como la sustitución de las columnas de madera que lo sustentaban por unas de hierro.
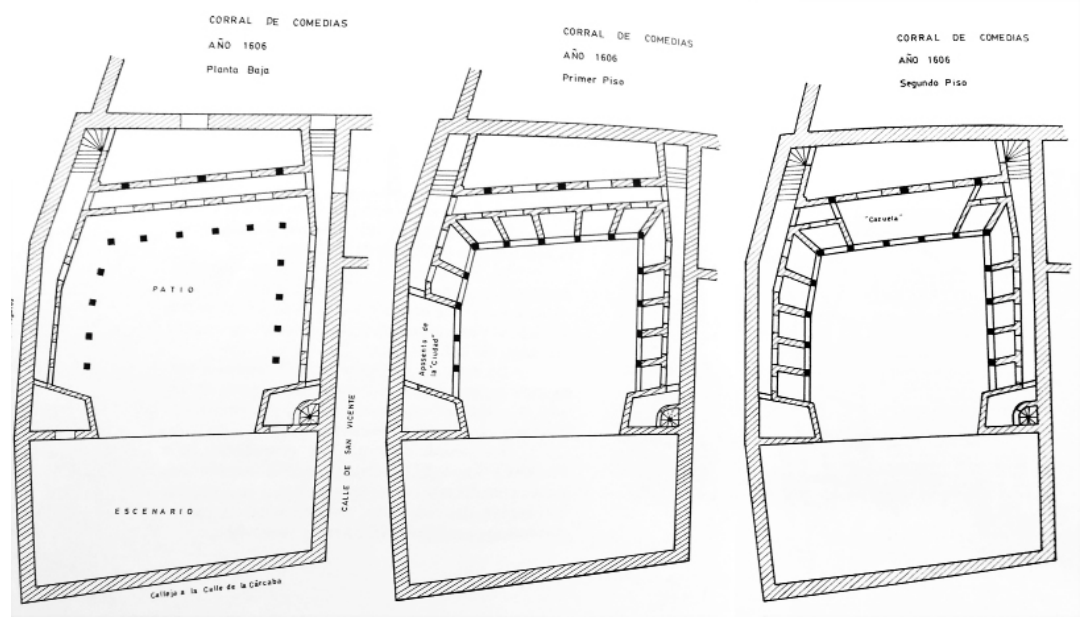

Figura 2. Plano del Teatro Principal en el siglo XVII. Fuente: Ventura, 1988: 100 y 101

El Teatro Principal fue adquirido por el Ayuntamiento en 1806, quien lo vendería a su vez en 1874 a Eduardo Calmarino. Este, construiría dos años más tarde-bajo los cimientos del antiguo patio de comedias - y con diseño de Eugenio Durán ${ }^{3}$, el conocido como Teatro Principal. El local poseía un aforo para novecientas localidades, con entrada independiente, cafetín y otras dependencias que fueron utilizadas — con el tiempo- para actividades culturales.

Al no edificarse ex novo tuvo que adaptarse al solar existente, un espacio en pleno corazón de la ciudad ubicado entre la calle San Vicente y dos pequeñas callejas que comunicaban con aquélla con la Cárcaba y Riego. Su planta en L complicaba la distribución interior, aunque el maestro de obras supo ubicar con facilidad vestíbulo, sala, escenario, cafetín bien decorado y otras dependencias que han sido para casinos pero que utilizadas únicamente para el teatro le darían más holgura, seguridad y comodidad. (Ávila, 2009: 225).

Junto al espectáculo teatral, surgirían nuevas representaciones al aire libre o en recintos habilitados en los que empresarios ambulantes - llegados a la ciudadofrecían circo, teatro de guignol y otras representaciones como los espectáculos pre cinematográficos. Ya a comienzos de 1800, gracias a Cesáreo Fernández Duro se tiene constancia de la llegada al Teatro Principal de la Compañía de Ópera Bernardo

3 Ávila de la Torre se basa (2009: 225) en la documentación conservada (AHPZa. MZa. Obras. Sign. 673-15). No hay datos sobre el responsable y artífice de la intervención del Coliseo, pero sus indicios le llevan a Eugenio Durán, ya que por aquellas fechas en Zamora no existía ningún técnico capaz de hacerse cargo de una actuación de esa envergadura. 
Lentini presentando junto a máquinas de caballos y títeres, las famosas sombras chinescas $^{4}$.

A parte de las representaciones teatrales y bailes de máscaras o de sociedad, se llevaban a cabo, como reza en los libros de cuentas: óperas y zarzuelas, juguetes cómicos, cuadros vivos, cuadros disolventes, títeres, equilibristas, volatines, físicos acróbatas y contorsionistas, sombras chinescas, juegos de manos, canariosa, perros, desfile de modelos, compañías de revista, flamenco, ballet, mítines políticos, etc. (Ventura, 1988: 69).

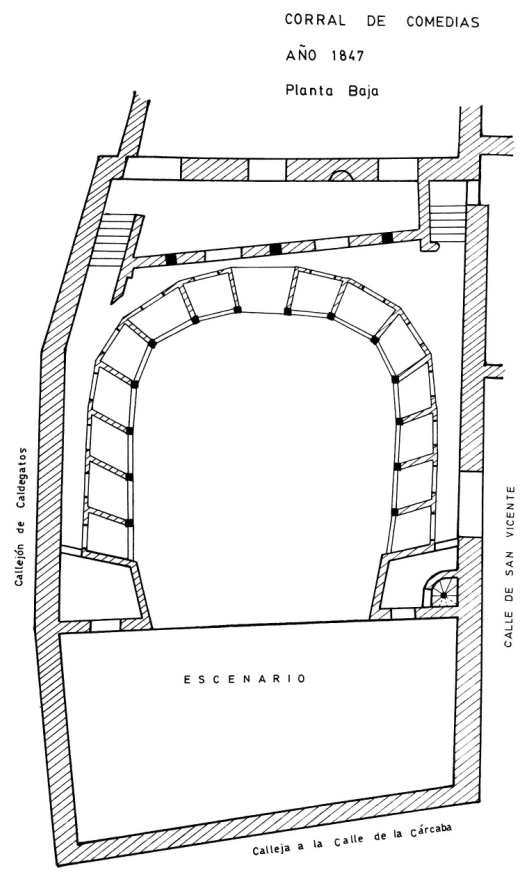

Figura 3. Plano del Teatro Principal en el siglo XIX.

Fuente: Ventura, 1988: 101

Pero no sería hasta el once de septiembre de 1897 cuando la fotografía en movimiento llegara a la ciudad, gracias a su presentación en el Teatro Principal. El kinetógrafo o Kinetoscopio ${ }^{5}$ en realidad se presentaba como un artilugio en el que el espectador, tras introducir una moneda, disfrutaba del espectáculo audiovisual de manera privada.

Los dos medios impresos de comunicación de la época - Heraldo de Zamora y El Correo de Zamora - se harían eco de la llegada del invento a la ciudad del Duero: "El sábado próximo abrirá sus puertas nuestro teatro para dar a conocer a este público el Kinetógrafo, maravilloso descubrimiento de la fotografía animada". "En

4 Fernández Duro, C. (1883). Apuntes de historia del teatro en Zamora. En Heraldo de Zamora, 21-I-1928, p.2.

5 El Kinetógrafo consistía en una cámara tomavistas tan grande que Edison la llamó la “caja del perro". Mientras el Kinetoscopio era el sistema para la visualización de esas imágenes, una vez impresionadas.

6 Heraldo de Zamora, 9-IX-1897. 
el Teatro Principal se dará a conocer esta noche el kinetógrafo, espectáculo que ha causado la admiración en todas las ciudades"

Pero hasta principios de 1898 no se presentaría el llamado Cinematógrafo Lumière, gracias al asentamiento de la Compañia Hispano Imperial Japonesa en el Teatro Principal. Como en otras ciudades españolas, el cinematógrafo se implantó en la sociedad a través de las barracas y las ferias en las que se exhibía el prodigioso invento. Al contrario que el kinetoscopio, el invento de los hermanos Lumière podía disfrutarse colectivamente, lo que hizo que triunfara en cada una de sus primeras proyecciones.

Se tiene constancia de que los empresarios lusos Marques y Azevedo — siguiendo la ruta del ferrocarril entre Asturias y Andalucía - fueron quienes se asentaron en Zamora a finales de enero de 1898 y donde filmaron la Salida del tren en la antigua estación, hoy desaparecida. La cinta con los cuadros — que emulaba a las que filmaron los Lumière unos años atrás - fue presentada el día siete de febrero en el coliseo y en las que se contaron por llenas las sesiones de los cuatro días de las proyecciones.

Aunque fue el lugar elegido para la primera proyección cinematográfica de Kinetoscopio, primero y más tarde del Cinematógrafo, lo cierto es que el Teatro Principal tan solo ofrecería representaciones teatrales durante estos primeros años del cine. Así lo reflejan las crónicas de los periódicos de la época que apenas informan sobre la exhibición de films en dicho recinto. El motivo de esta falta de proyecciones fue principalmente, la proliferación de barracas y pabellones que recalaban en Zamora con motivo de las fiestas. Como los dueños del teatro no veían negocio a las películas, fueron empresarios ajenos al coliseo los que decidieron explotar el cinematógrafo a partir de la segunda década del siglo xx. El testimonio lo muestran los documentos encontrados en el Archivo Histórico Provincial y que hacen referencia al pago del impuesto del Timbre del Estado, que se fijaba en un diez por ciento de la recaudación en taquilla.

Durante esos primeros años la prensa narraba las sesiones que se ofrecían en el Teatro Principal y en los cinematógrafos ambulantes que pululaban por la ciudad. Estas proyecciones eran bien distintas dependiendo del local de exhibición. Mientras que el Teatro Principal, el invento servía como colofón a los números teatrales y representativos, en las barracas de madera las sesiones de cine se intercalaban con teatro de títeres y marionetas. También las localidades en uno y otro local eran bien distintas. Los asientos de las barracas eran bastante precarios y sucios. Totalmente diferente a los del coliseo, que constaban - la mayoría - de butacas de madera o - en el peor de los casos- de bancos corridos. No se disponen de datos sobre los precios de las entradas, pero según afirman los historiadores cinematográficos, analizando los datos de otras ciudades españolas, el cine estaba al alcance de todos pero en condiciones bien distintas (Díez Puertas, 2003: 26-27)

\section{Cinematógrafo y varietés}

Con el tiempo, las películas comenzaron a ser bastante monótonas, lo que provocaría la falta de atención del público. De ahí que se comenzaran a importar cintas de las productoras más importantes de Francia, como Pathé y Gaumont. Aunque 
seguía existiendo un problema: la corta duración de los filmes, que provocaba que los empresarios de todo el país tuvieron que ofrecer algo más por el precio de la entrada. Por eso, las sesiones se intercalarían con números de varietés, incluyendo animales, imitadores, cupletistas y ventrílocuos. Durante las veladas se contaría con la participación de los llamados charlatanes o explicadores, que amenizaban las proyecciones con sus vivas voces, perdurando estos hasta bien entrada la década de los años treinta. Personalizaban las películas a su gusto, repitiendo escenas con comentarios jocosos y animando con bastante silabeo y en voz alta para que el público participara en su representación (Castrillón \& Martín, 1997: 90).

El explicador solía ser un individuo de reconocida facilidad de palabra y convincente tono, que, ayudado por un puntero, iba señalando en el mismo lienzo de plata las figuras que iban apareciendo y dando las originalísimas explicaciones para que el vulgo pudiera comprender lo que iba sucediendo. (Méndez Leite, 1965, I: 65).

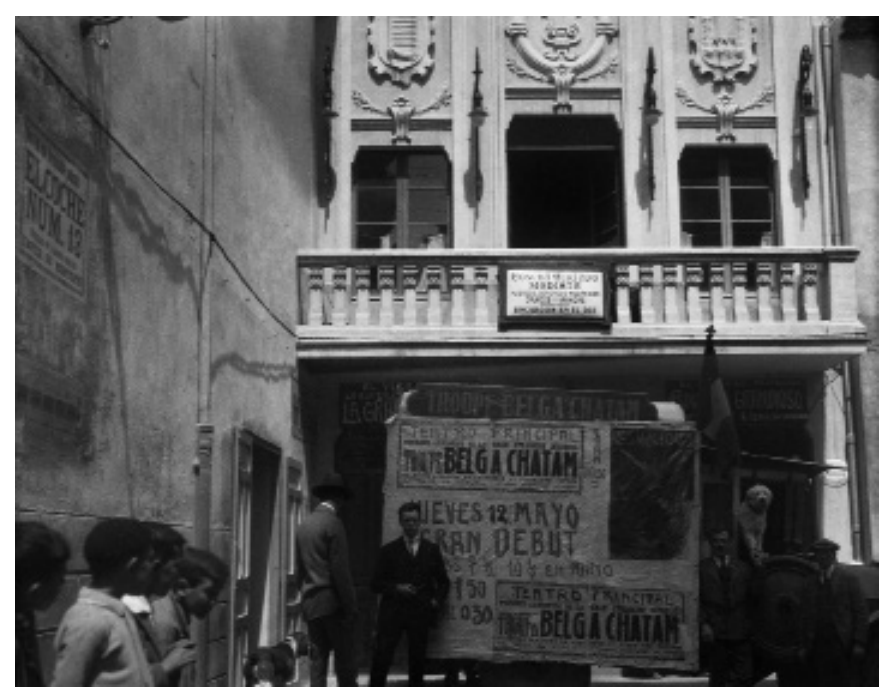

Figura 4. El Teatro Principal en 1927. Autor: Somoza/Foto Duero. Fuente: Filmoteca de Castilla y León. Colección Caja España/Duero

Al igual que sucedería en la mayor parte de Castilla, en Zamora el encargado de esta labor fue el propio proyeccionista que recitaba de memoria pasajes para divertimento de la clientela en los llamados cinematógrafos errantes. Con el tiempo, los explicadores fueron sustituidos por los dobles, personas que "doblaban" en directo el posible diálogo que mantenían los actores en pantalla, así como los ruidos procedentes de la misma.

No se especifica el coste de las entradas a dichas proyecciones, aunque sí que se alude a lo económicas que eran las mismas provocando que, por primera vez, se combinara la gente del vulgo con los personajes más distinguidos de la ciudad. El 
Teatro Principal ofrecía ya tres sesiones diarias de cinematógrafo y varietés: 6,30; 7,30 y $10,30^{8}$.

Si las varietés son una amalgama multiforme de espectáculos, a veces de compleja filiación, pero fácil de hilar para el público avisado, dentro de ellas puede abrirse una nueva categoría espectacular que, desde hace ya años, hemos venido llamando cinematógrafo y varietés, tal como la conocían los públicos de principios de siglo xx, en la que medró el cinematógrafo (Madrid, 2009: 24).

A partir de 1915, el coliseo competiría en igualdad de condiciones con las salas estables. Los cinematógrafos Buenaventura y Royalty ${ }^{9}$ fueron rivales del Principal, hasta que, un año más tarde, apareciera el Nuevo Teatro con su novedad y gran aforo para cerca de mil localidades. En el Archivo Municipal de Zamora se muestran los datos de la capacidad ${ }^{10}$ que poseía el coliseo capitalino, gracias a las solicitudes enviadas por parte de Enrique de Nicolás ${ }^{11}$ al Ayuntamiento. Estos documentos son pagos del impuesto del timbre de los billetes correspondientes a las funciones que se celebraban en el teatro

El recinto del Principal —en cambio - poseía 27 localidades en palcos y plateas, 170 butacas, 26 delanteras de galería, 98 asientos de galería, 69 delanteras de paraíso y 266 asientos de paraíso, llegando a un total de 656 localidades. También en el citado impuesto se refleja el precio de las localidades: palcos y plateas sin entrada a nueve pesetas; butacas con entrada a dos pesetas, delanteras de galería con entrada a 1,50 pesetas; asiento de galería a una peseta; delantera de paraíso a 1 peseta; y la entrada general a 1,70 pesetas ${ }^{12}$. En España, las clases medias bajas urbanas (tenderos, artesanos, empleados, funcionarios, etc.) y sus niños, fueron la primera plataforma social sobre la que se construyó la experiencia cinematográfica de ir al cine y de rebote la consolidación del cine como una forma de ocio (Palacio, 2010: 271).

Durante ese año se decidiría - por parte del Ayuntamiento- el cierre temporal del Teatro Principal hasta que no se arreglasen los desperfectos en el mismo, ya que podrían causar incidentes imprevistos. Las obras que se llevaron a cabo en el Coliseo consistieron en la creación de una puerta en la calle de San Vicente, la construcción de una escalera que condujera al salón de descanso, la puesta en marcha de una caldera de calefacción moderna, puertas correderas para palcos y plateas, instalación eléctrica del escenario independiente y aislada del resto del teatro, espacio suficiente entre filas de butacas; y lo que es más importante, colocar una cabina de cinematógrafo

8 Debido a la gran afluencia de público durante estos espectáculos -no solo en Zamora, sino en toda España- las autoridades del Estado se vieron en la necesidad de dictar unas normas de higiene y seguridad en los locales donde se exhibían cinematógrafos para prevenir los continuos incendios y sucesos producidos por todo el mundo. Todo local debía de contar con chimeneas para la salida de humos, instalación eléctrica independiente y ubicación opuesta de las cabinas de cine al lugar por donde entraban los espectadores. También en 1913, el Gobierno de la Nación publicó una Real Orden del Ministerio de la Gobernación para la creación de una policía específica, la cual debía vigilar las condiciones de construcción de los edificios que albergaban espectáculos públicos.

9 Estos cines en realidad eran grandes pabellones instalados durante las épocas de fiestas. Poseían grandes aforos y ofrecían espectáculos de variedades.

10 A.H.P.Za. A.M.Za. Propios y arbitrios. L-2-197.

11 Enrique de Nicolás, a la sazón, capitán de infantería, sería el impulsor de la construcción del Nuevo Teatro.

12 A.H.P.Za. A.M.Za. Propios y arbitrios. L-2-197. 
en el lado opuesto a la entrada de los espectadores. Para prevenir incendios se acordó también la construcción de varias chimeneas sobre el escenario. Sin duda, este fue un punto de inflexión en la exhibición del cinematógrafo en la capital. Durante 1913 a 1915, otros empresarios ávidos en el negocio de la exhibición, ofrecían sesiones de cine y varietés. Aunque el propietario seguía siendo Calmarino, lo cierto es que — según la Matrícula Industrial - fueron tres las personas que proyectaron películas en el Coliseo: Constantino F. Arango, Saturnino Girón y Alejandro Sanvicente. Este último conseguiría los mejores contratos con las principales distribuidoras, lo que hizo que se afianzara como un gran exhibidor - no solo en la ciudad - sino por toda la provincia ${ }^{13}$. Ya en durante el verano de 1918, Julio Ramos firmaría un contrato para ofrecer proyecciones de cine y representaciones teatrales, gracias a la asociación que realizó con Sanvicente, que conocía el mundo de las representaciones y había ofrecido anteriormente veladas en los dos teatros de la ciudad. También en septiembre de ese año, Manuel Alonso Priz ${ }^{14}$ celebraría sesiones de cine creando un económico abono por setenta y cinco pesetas. Así, los espectadores podían disfrutar de cincuenta días de función que incluían cien "secciones" de cine ${ }^{15}$ y varietés; y también dos representaciones de compañías teatrales.

\section{Crisis de exhibición en Europa}

A finales de la década de los diez se produce la consolidación del medio, gracias a las producciones cada vez más largas y refinadas de las productoras extranjeras. Las cintas francesas e italianas serán muy consumidas en Zamora, así como las películas norteamericanas y la nueva producción española que comenzará a cosechar gran éxito debido principalmente a la crisis de producción del mercado europeo motivada por la Primera Guerra Mundial.

Con la Gran Guerra los mercados europeos se resienten, España está desabastecida de material que no sea norteamericano. [...] Los programas de cine se alargan y las películas ya se cuentan por miles de metros y por varias horas de duración, e incluso, con los seriales, por días, en los que se mantiene el interés del respetable (Madrid, 2009: 47).

Durante la Semana Santa de 1919, Avelino García Casado, a la sazón empresario del Teatro Principal, exhibiría la cinta Vida, pasión y muerte de nuestro Señor Jesucristo (La vie et la passion du Christ, Ferdinand Zecca, 1902), anunciando a

13 Se tiene constancia de que Sanvicente ofreció sesiones de cine y varietés en el Teatro del Jardinillo de Benavente y el Teatro Latorre de Toro durante la segunda década del siglo xx.

14 Heraldo de Zamora, 4-IX-1918, p.2.

15 Es de destacar el llamado cine por episodios, llegando a permanecer en las carteleras hasta la llegada del sonoro. En 1925 el francés Pierre Gilles-Veber pronunciaría un discurso en la Association des Amis du Cinéma sobre la evolución del ciné-feulleton: El género de las películas en episodios es absolutamente francés. La primera persona que dividió una película en varios capítulos fue Louis Feuillade en 1913 con las aventuras de Fantomas. De todos los films franceses que mayor éxito obtuvieron antes de la guerra apuntamos Los Miserables y Rocambole de la casa Pathé o Fantomas de la Gaumont. En España, el primer film por episodios fue Los misterios de Nueva York, cinta distribuida por Pathé de la novela publicada en Le Matin por Pierre Decourcelle. 
través de la publicidad en la prensa como film tomado en colores ${ }^{16}$. También durante esta época se comenzó a invitar a la prensa y las figuras influyentes de la sociedad a las première. Con ello, el empresario creaba otro canal más de comunicación para llegar al gran público. Junto a ellos también eran invitadas las autoridades civiles, militares y eclesiásticas, las cuales se convirtieron en otro medio publicitario gratuito para la empresa.

A comienzos de la década de los años veinte se crearon las llamadas sesiones "monstruo" de cuatro de la tarde —infantil—, así como dos sesiones de siete de la tarde y diez de la noche. Las variedades iban poco a poco siendo absorbidas por sinfonías de la orquesta contratada por el teatro, junto a películas cortas, la mayoría cómicas. Los precios de las localidades descendieron considerablemente con respecto a la pasada década, debido principalmente a la competencia entre el Principal y el Nuevo Teatro. Estas cantidades dependían de la clase de localidad ${ }^{17}$ :

- Palcos y plateas sin entrada: 1,50 (infantil) y 4 noche

- Butaca con entrada: 0,25 (infantil) y 0,75 noche

- Delanteras de galería: 0,20 (infantil) y 0,60 noche

- Galería: 0,20 (infantil) y 0,50 noche

- Delanteras de paraíso: 0,15 (infantil) y 0,35 noche

- General: 0,10 (infantil) y 0,25 noche

Finalizando 1923 el Teatro Principal fue vendido por setenta y cinco mil pesetas a los empresarios Eduardo Gutiérrez, Fernando Gutiérrez, Vicente Tomé y César Prieto "amantes de las gloriosas tradiciones" 18 proponiéndose estos la renovación completa del coliseo a corto plazo $^{19}$. Los nuevos dueños inaugurarían la sala con una gala en la hora vermouth ${ }^{20}$ del veinticinco de noviembre y donde ofrecieron sus primeros ingresos para financiar una corona destinada a la Virgen de la Soledad del artista zamorano Ramón Álvarez, tan venerada y querida en la ciudad ${ }^{21}$. Los socios se propusieron rehabilitar por completo el antiguo patio de comedias, por lo que clausurarían el teatro entre marzo y noviembre de 1924. El proyecto de obra fue realizado por Gregorio Pérez Arribas, el cual construiría los camerinos que ocupaban parte del callejón y le daría el aspecto — sala y fachada — que actualmente se puede contemplar después de las reformas producidas por Somoza y Vellés en 1988. En el resumen de la memoria — previa a la rehabilitación publicada en El Correoestos dos arquitectos, informan de las ochocientas treinta plazas de aforo con las que contaba el teatro: cuatrocientas ocho localidades en platea, doscientas para el anfiteatro y doscientas veinte destinadas al paraíso.

16 La película producida por la casa francesa Pathé Frères reunía treinta y nueve escenas en cuatro episodios, cuya duración era de cuarenta y cinco minutos.

17 El coste de las entradas viene expresado en pesetas y en céntimos.

18 Heraldo de Zamora, 26-X-1923, p.1.

19 El Correo de Zamora, 25-X-1923, p.2.

20 La hora vermouth se establecía como la de media tarde, sobre las siete o siete y media.

21 Heraldo de Zamora, 22-XI-1923, p.2. 
La planta del teatro sufrió algunas modificaciones para rentabilizar su mantenimiento, convirtiéndolo en sala de cine. La fachada que se conserva, se realizó en 1924, obra de Gregorio Pérez Arribas, con una portada con reminiscencias renacentistas y barrocas: cartelones, guirnaldas, escudos; muy al gusto del eclecticismo que se respiraba en la época. (Herrero, 2006: 170-171).

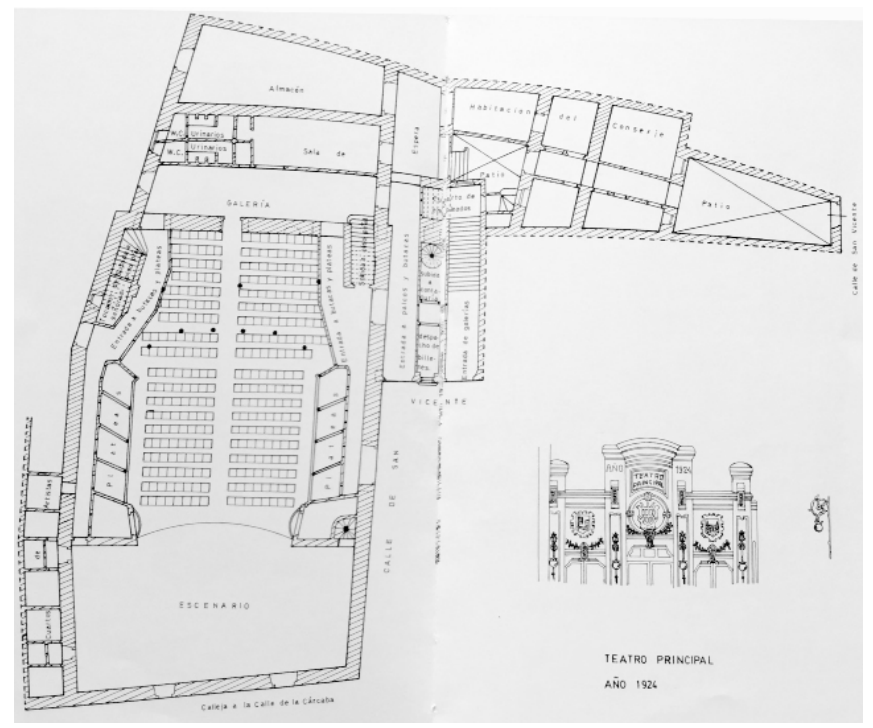

Figura 5. Plano del Teatro Principal después de su gran reforma en 1924. Fuente:

Ventura, 1988: 102-103

El nuevo Teatro Principal se inauguraría el jueves veinte de noviembre con nuevas dependencias, y un ambigú para los clientes durante los descansos de las representaciones y proyecciones. La distribución de las más de ochocientas treinta localidades, así como sus precios quedaron de la siguiente manera:

- Diez plateas y diez palcos con cinco entradas ${ }^{22}$.

- 324 butacas: 0,60 (infantil) y 0,75 noche.

- 129 entradas de palco: 2,5 (infantil) y 3 noche.

- 56 delanteras anfiteatro: 0,30 (infantil) y 0,40 noche.

- 52 localidades de anfiteatro: 52: 0,40 (infantil) y 0,50 noche.

- Treinta delanteras general: 0,30 (infantil) y 0,40 noche

- 125 localidades de general: 0,20 (infantil) y 0,25 noche.

En esa época se instauraría la llamada "contratación por lotes" que venía a sustituir al alquiler de cintas por unidades. Es decir, el empresario-exhibidor era obligado a contratar a la casa distribuidora un catálogo completo de películas ofertadas, con lo que si resultaba un éxito de taquilla, la sala de exhibición debía abonar un cantidad

22 El palco se compraba con cinco entradas y generalmente iban asociadas a familias adineradas adquiriendo abonos para los espectáculos celebrados durante una temporada. 
variable a la distribuidora como parte del beneficio económico que le había supuesto (Montes, 2016: 40).

Nos encontramos con el establecimiento del alquiler de películas, dejando atrás el arcaico y lento sistema de venta directa de las copias de los films. Este factor convirtió a los distribuidores en intermediarios entre la manufactura del film, la realización y la producción, y el consumo del mismo, la sala de exhibición y el público. (Montes, 2016: 34).

Los cuatro socios del coliseo ofrecerían espectáculos teatrales y cinematográficos durante poco más de dos años, ya que en junio de 1926 - tras la dura competencia con el Nuevo Teatro y los problemas con las distribuidoras para conseguir los filmes más selectos - se verían obligados a vender el negocio. No se tienen datos sobre cuál fue el coste de la venta, aunque sí se sabe que el Teatro Principal fue comprado por Alejandro Sanvicente, quien ya había ofrecido sesiones teatrales y cinematográficas en Zamora y provincia. El avispado empresario se haría con los contratos de exhibición de las principales distribuidoras como United Artists, Gran Luxor Verdaguer, Paramount, Metro Goldwyn, United Artists, UFA, Gaumont, First Nacional y FOX, así como la edición de una pequeña publicación con periodicidad semanal en la que se informaba de las novedades - tanto cinematográficas como teatrales - celebradas en el coliseo ${ }^{23}$. Durante esos felices años veinte se presentarían las últimas técnicas de la cinematografía, como el cine en el entonces primitivo Technicolor con la cinta El Pirata negro (The Black Pirate. Albert Parker, 1926). También se tiene constancia de la adquisición de un nuevo proyector de la marca Krupp-Ernemann, modelo Imperato II ${ }^{24}$ y la construcción - aneja al coliseo- de una sala de pruebas para las cintas cinematográficas ${ }^{25}$. Pero el gran acontecimiento de la década llegaría a comienzos de 1928 con el estreno de Metrópolis — La ciudad sobre las ciudades-(Metropolis, 1927)26, del director alemán Fritz Lang. Zamora sería una de las primeras ciudades de España donde se estrenaría por vez primera la cinta, colocándose en el frontispicio del coliseo un gran anuncio luminoso, así como varias fotografías del film. Para rematar la difusión del film, una de las páginas del Heraldo fue íntegramente dedicada a reproducir el acontecimiento, cuyos precios oscilaban entre los cincuenta céntimos y las seis pesetas ${ }^{27}$. 


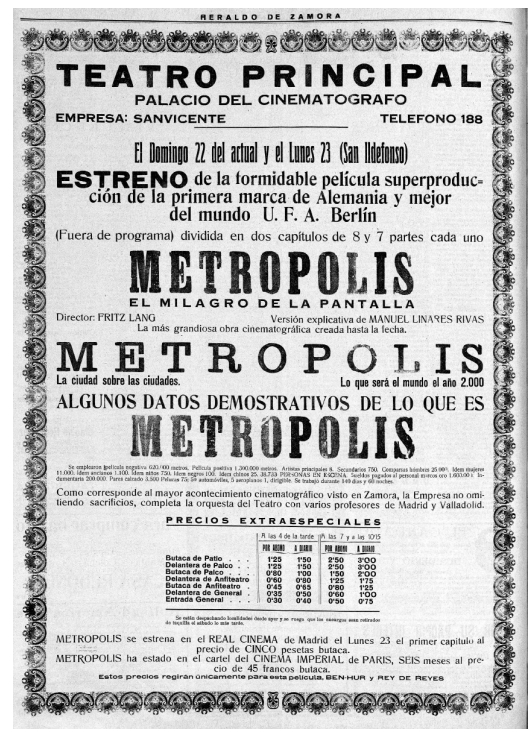

Figura 6. Publicación del estreno de Metrópolis en la prensa zamorana.

Fuente: Heraldo de Zamora, 19-I-1928, p.4.

Sin duda esta fue la época de los estrenos más representativos del cine mudo como Amanecer (Sunrise, F. W. Murnau, 1927) , El Circo (The Circus, Charles Chaplin, 1927), El Legado Tenebroso ${ }^{28}$ (The Cat and the Canary. Paul Leni, 1927), El demonio y la carne (Flesh and the Devil. Clarence Brown, 1926) o El Cameraman (The Cameraman, 1928).

\section{La transición al cine sonoro}

Desde su nacimiento el cinematógrafo siempre estuvo asociado al sonido. Las cintas mudas, por lo general, se proyectaban acompañadas de un pianista o pequeñas agrupaciones de músicos, los cuales interpretaban bellas melodías para el disfrute del público ${ }^{29}$. Durante finales de los años veinte la empresa del Principal incluiría también en los intermedios — ya que solo se realizaba durante las proyecciones - , la interpretación de piezas musicales por parte de la banda de música del Regimiento de Toledo, dirigida esta por Arturo Luis Villanueva. Complementando a la música, en 1928 se experimentaría con películas como Una aventura en el Riff ${ }^{30}$, en la que se presentaban sonidos de disparos, ametralladoras

28 Uno de los films precursores del género de terror. (Ruiz, L.E. 1997: 313).

29 Ya en 1926 se ofrecen las primeras exhibiciones de sistemas de cine en España "siendo en el Teatro Lírico de Valencia, el 2 de mayo de ese mismo año, donde el cineasta presenta el sistema sonoro de los daneses Petersen y Poulsen que, perfeccionado y comercializado, se denominará Gaumont-Petersen-Poulsen”. Durante esos años hasta 1929 aparecen en el mercado español diferentes procedimientos de cine sonoro. (Santos, 1995: 151).

30 Se supone que el título original de la cinta es Alma rifeña (José Buchs, 1922), donde se plasmaría la labor del ejército español en tierras marroquíes. 
y cañones a través de un procedimiento eléctrico para conferir mayor realidad a la escena y que mostraba "la más viva sensación de verismo a la película" 31 . A principios de 1929, el Heraldo de Zamora, se haría eco del invento de Lee De Forest: el Cinefón, cinta esta que agrupaba varias películas cortas filmadas por dicho procedimiento ${ }^{32}$. Se desconoce quién fue exactamente la persona o personas que recalaron con el prodigioso invento. Lo que sí está claro es que la empresa era la Hispano de Forest Film, fundada en Barcelona en 1927 por Feliciano Manuel Vitores, Enrique Urazandi y Agustín Bellapart, tras adquirir estos, la patente del Phonofilm para España y Portugal. Es de suponer que Agustín Riu — director técnico de la empresa - y/o Vicente Oliveres — instalador de equipos y proyeccionista de películas - serían las personas encargadas de la gira española del aparato, asentándose en Zamora el catorce de enero (Fernández Colorado, 2002). Un día más tarde la primera película sonora - Cinefón - sería presentada en el Teatro Principal. En realidad, fueron fragmentos de actuaciones de Conchita Piquer ${ }^{33}$ y Elvira de Amaya, junto a cuentos de Ramper y conciertos por orquestas argentinas. Para que los espectadores no confundieran el PhonoFilm con otro sistema de cine sonoro anterior, se les haría entrega de un sobre que contenía un papel explicativo de la técnica utilizada, así como una pequeña tira de negativo que incluía la banda de sonido. Los precios del día de su estreno fueron desde los veinticinco a los treinta y cinco céntimos en general y de una a dos pesetas en butaca de patio. El estreno causó mucha expectación y aunque el sonido necesitaba perfeccionarse en el timbre y los matices de la voz, lo cierto es que los espectadores quedarían abrumados por la sincronización exacta entre sonido e imagen. Durante enero de 1930 se produciría el estreno en el Teatro Principal de la primera película sonora realizada por este sistema. El misterio de la Puerta del Sol ${ }^{34}$ (1929) de Francisco Elías. El film estrenado el cuatro de febrero a precios que oscilaban entre las dos y las tres pesetas; fue criticado duramente por la prensa local por su mediocridad sonora.

Los diálogos cuesta entenderlos y las voces suenan mecánicas y forzadas. El estreno de "El misterio de la Puerta del Sol" es un completo desastre. Problemas de sincronía, voces demasiado aflautadas... La película se retira del cine y no vuelve a exhibirse (Martínez, 2017).

31 Heraldo de Zamora, 9-VI-1928, p.4.

32 Los sonidos se registraban en una banda a la izquierda de la imagen -lo que se conoce como banda sonora óptica-. Para su lectura se utilizaba una potente lámpara pasando esta por una pila fotoeléctrica donde se leía la banda -líneas blancas desiguales-. Cuando la líneas se presentaban estrechas, el sonido era bajo y viceversa. El proceso sonoro se reproduciría incidiendo una fuente de luz a través de la banda de audio, con lo que, dependiendo de la anchura la línea, la luz que traspasaba la banda, variaría. Finalmente el audión detecta la luz, convirtiéndola en energía eléctrica, que al oscilar, se transforma en sonido gracias a los altavoces.

33 Las piezas musicales de Conchita Piquer filmadas en 1923 eran: Couplé andaluz, Jotas aragonesas y Fado luso. Fueron encontradas recientemente por el investigador Agustín Tena en la Biblioteca Nacional del Congreso de los Estados Unidos, cuyo propietario en ese momento era un viejo coleccionista llamado Maurice Zouhary. http://www.rtve.es/alacarta/videos/imprescindibles/imprescindibles-concha-piquer-04-11-10/922120/

34 La cinta contaba con escenas mudas y sonoras y venía precedida de su estreno el once de enero en el Coliseo Castilla de Burgos, provincia de la que era natural su productor, Feliciano Vitores. Al no haber contado con los suficientes apoyos para proyectar el film en Madrid o Barcelona, Vitores logró acondicionar este Coliseo, donde la crítica se mostraría "benevolente ante las notables deficiencias técnicas" (Colorado, 2002). 
Debido al estrepitoso fracaso que supuso la presentación del Phonofilm en el Teatro Principal, Sanvicente apostaría unos días más tarde por otra patente, el Vitaphone ${ }^{35}$. Aunque no estuvo exento de problemas en cuanto a su manipulación e inversión en nuevos equipos, lo cierto es que el nuevo sistema sonoro fue inaugurado - a pesar de contar con poco público - con el estreno del film El escándalo de Broadway ${ }^{36}$ (Broadway Scandals. George Archainbaud, 1929). El clima que reflejaba la cultura en Zamora era de desconcierto ante el nuevo arte parlante, por lo que los medios de comunicación aconsejarían la bajada de los precios y la permanencia un solo día de las películas estrenadas.

\section{El monopolio de la exhibición}

Durante la década de los años treinta, Alejandro Sanvicente se haría con la gestión del Nuevo Teatro, con lo que llegó a controlar el mercado de la exhibición en la capital a través de los dos teatros. Fue en este momento cuando se produce la brecha en lo que se refiere al precio de la entrada del espectáculo cinematográfico. Dependiendo de las distribuidoras, los precios de las localidades en Zamora fluctuaban entre los setenta y cinco céntimos a la peseta y media para la general; y desde la peseta a las dos para la butaca de patio ${ }^{37}$. Las casas distribuidoras de la época se ubicaban en Madrid o Barcelona, excepto Cifesa, en Valencia. Estas empresas alquilaban las cintas a los exhibidores como Sanvicente, desembolsando este el precio de alquiler de la película y los portes de ida y de vuelta del material que, generalmente llegaba por tren ${ }^{38}$.

A finales de enero, Sanvicente realizaría importantes reformas en el Principal con el fin de que la instalación sonora fuera una de las más importantes del país. Para ello la cinematografía Artea instaló un nuevo amplificador para el proyector que también contó con nueva cabina instalada en la entrada general. El espacio contaba con un techo de uralita y doble tabique para que el ruido de los aparatos de proyección quedase aislado de la sala donde se encontraban los espectadores.

35 El sistema Vipahone de la Warner Brothers producía un sonido clarividente, así como sincronizado con la imagen, aunque resultaba costoso tanto comercial como económicamente. Cada lata de película iba emparentada a un disco fonográfico, lo que repercutía en el peso para su transporte y manipulación. Esto trajo consigo algunos problemas como la sustitución de algunas películas sonoras por otras, debido a que el trabajo de las casas distribuidoras - película + disco-sobrepasaba por la demanda de material sonoro o la llegada de discos rotos o rallados, lo que suspendía la proyección de los films. Heraldo de Zamora, 7-X-1930, p.2.

36 Según el Heraldo (20-III-1930, p.2), se eligió este film porque fue el mayor éxito que había tenido en el Real Cinema de Madrid de entre todas las películas sonoras proyectadas hasta la fecha.

37 Díez Puertas (2003: 32-34) establece siete factores que influyeron en el precio de las salas: la categoría de la sala de cine, la clase de localidad, el horario, el día de la semana, el tipo de programa, la situación geográfica y la concurrencia.

38 Montes (2017: 74) señala a Enrique Viñals como la persona encargada de distribuir en Zamora -región centro- las películas de las casas Cinamond Films, Art Film, Repertorio M. de Miguel y Selecciones ECA. Saturnino Ulargui y la distribución cinematográfica en el contexto de la II República Española. Tesis Doctoral. Salamanca, España: Universidad de Salamanca. 
El porcentaje de cine parlante iba creciendo cada temporada, de ahí que Sanvicente en 1932 adquiriera dos proyectores de la marca OSSA (Orpheo Syncronic, S.A.). Uno, en febrero, para el Nuevo Teatro ${ }^{39}$, y otro comprado en septiembre para el Principal ${ }^{40}$. Fue en esta época donde se produjo una gran crisis en la exhibición cinematográfica, provocada primero por la situación social y política que atravesaba el país, y segundo, por el aumento del precio de las localidades. Estas poseían un alto precio impuesto por los distribuidores de cintas parlantes ${ }^{41}$. De hecho, la asistencia a una proyección sonora se antojaba bastante elitista, similar situación a la que había ocurrido en 1897 con la llegada de las primeras imágenes en movimiento a la capital. De hecho, esta situación llegó a empeorar, ya que Sanvicente aprovecharía su monopolio en Zamora, para subir el precio de las localidades de ambos teatros, llegando a cobrar - a principios de 1934 - dos pesetas con diez céntimos la butaca de patio.

Con la llegada de la Guerra Civil, el circuito de exhibición se paralizó, lo que provocaría que el $90 \%$ de las proyecciones que se exhibían en el Principal fueran reestrenos de otras temporadas. Aun así, los estrenos en Zamora eran bastantes mucho más numerosos, comparándolos estos, con los de otras ciudades españolas durante la contienda. Dos son las causas de este porcentaje de estrenos. La primera fue la situación de ciudad en la retaguardia que poseía Zamora en la Guerra Civil ${ }^{42}$ y la segunda causa se encuentra en la inclusión del coliseo dentro de un circuito de exhibición del noroeste del país ${ }^{43}$.

Zamora dejó de ser la ciudad tranquila donde nunca pasaba nada. Y aunque siempre estuvo alejada de los frentes de combate la guerra no por ello fue aquí menos cruenta, pues el hambre y las privaciones, con ser muchas, no fueron nada comparadas con la feroz represión desatada en los primeros meses (Casquero, 2008: 6).

39 El equipo Supermodell era lectura óptica. Costó cien mil pesetas y se anunció como "la mejor instalación del mundo fabricada en España con altavoces ortofónicos de columna de aire”. Heraldo de Zamora, 6-II-1932, p.2.

40 El modelo era Extra Super Modell.

41 Las entradas en Zamora ascendieron a una peseta con veinticinco céntimos.

42 Según el estudio de Ramiro Cebrián (1986: 142) Zamora fue junto con Ávila y Toledo, las provincias con mayor índice de violencia política durante la Guerra Civil. Los primeros meses del conflicto estuvieron marcados por la búsqueda, tortura y matanza de los que los golpistas consideraban "enemigos del alzamiento" y donde no se libraron las mujeres, con un diez por ciento del total de muertes. En Blanco Rodríguez (Coord.). A

43 "Empresas Reunidas" sociedad formada por los empresarios de espectáculos del noroeste del país, establecería su sede en el Teatro Principal de Zamora. Alejandro Sanvicente fue su presidente, de la que formaban parte los dos coliseos capitalinos, el Lope de Vega de Valladolid, el Teatro Cervantes de Segovia, el Principal de Burgos, Principal de Palencia, los Principal y Alfageme de León, teatros Bretón y Liceo de Salamanca, el Gran Teatro de Benavente y el Gullón de Astorga. Su cometido no era otro que la creación de tres compañías que pudieran ofrecer espectáculos de zarzuela y comedia por dichos coliseos, aprovechando los mismos para ser ofrecidos a otros circuitos del resto de España -como el de Levante-para intercambiar espectáculos entre ambas empresas. El Correo de Zamora, 22-IX, 1933, p.2. 


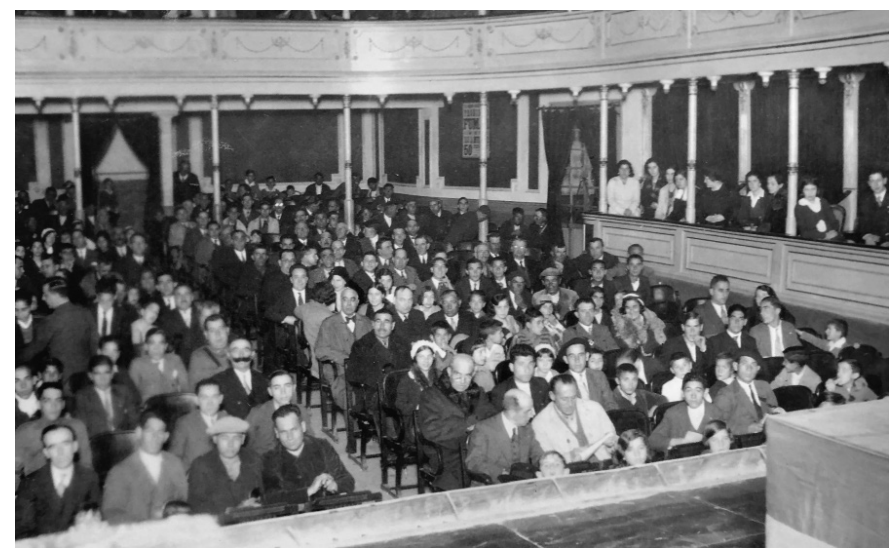

Figura 7. Interior del Teatro Principal en la década de los años treinta. Fuente: Somoza/Foto Duero. Colección García Rubio.

Por aquella época todas las películas ya eran aprobadas por la censura de Sevilla, así como los primeros noticiarios de la Guerra, precedente al NO-DO ${ }^{44}$, como $\mathrm{La}$ fiesta de la bandera ${ }^{45}$ o De Vigo al frente de Mérida ${ }^{46}$. Se consolidaría un cine de reportaje, un género de cineperiodismo testimonial definido por la inmediatez y por la prioridad de la información factual acerca de lo noticiable (Gubern, 1986: 11). Fueron también numerosos los films patrióticos que se estrenaban en las pantallas de la capital como Asedio y toma de Málaga o Actualidad UFA, este último "con sensacionales reportajes de Japón, Alemania e Italia"47. También destacaron los films que hacían referencia a Italia — país aliado - con cintas como Potencia Naval Italiana, Como Italia salió de Abisinia, Imperio, La inquebrantable amistad ItaloAlemana, Labor civilizadora de Italia en Etiopía y El Ejército de la Italia Fascista, distribuidas por el Instituto Nacional $\mathrm{LUCE}^{48}$ alpino y que tuvo gran acogida en la Zamora nacional, calificadas por la prensa de la época como "magnífico documento" y enalteciendo la labor de Mussolini.

\section{La etapa franquista}

Con el fin de la guerra se produce una bonanza en la exhibición cinematográfica en la ciudad y, por ende, el final del monopolio de las salas comerciales de cine

44 Fox (1919) y Universal (1913) en los años diez; y Paramount y Metro en 1927, ya realizaban noticiarios como género establecido cuya duración variaba entre los cinco y quince minutos. Sánchez-Biosca \& Tranche, 1993: 21).slaman, R. 86: p.

45 Heraldo de Zamora, 15-XII-1936, p.2.

46 Heraldo de Zamora, 16-XII-1936, p.4.

47 Heraldo de Zamora, 13-VIII-1937, p.2.

48 Gubern (1986: 78) cita los estudios de Oms, Fernández Cuenca y Argentieri, los cuales destacan la contribución del Instituto Nazionale Luce a la difusión y a la manipulación propagandística de las imágenes de la guerra de España. Es de sobra conocido que estos noticiarios Luce incluían comentarios profranquistas, anticomunistas, así como connotaciones religiosas que hicieron de la guerra una cruzada para las fuerzas insurrectas. 
por parte de Alejandro Sanvicente. A principios de los años cuarenta aparecería la primera sala exclusiva de cine en la ciudad, promovida por la familia Barrueco. De ahí que Sanvicente destinara el Principal a representaciones teatrales y a las grandes superproducciones cinematográficas, trasladando el resto de películas al Nuevo Teatro $^{49}$. Gran visionario, don Alejandro se convertiría en el presidente del Montepío Nacional de Empresarios de Espectáculos.

En 1956 inauguraría una nueva instalación sonora de la marca Westtex, cuyos altavoces poseían lente acústica y sonido estereofónico ${ }^{50}$. También se cambió la vieja pantalla por una panorámica de la marca Miracle Mirror con ocho metros de anchura por cinco con veinte metros de altura. Por último, se aprovecharían los nuevos equipos para ofertar la sesión continua con dos películas a partir de las cuatro y media de la tarde ${ }^{51}$.

Durante los años sesenta y tras su fallecimiento, los herederos de Sanvicente reformarán el Principal, convirtiendo algunos de sus palcos en entradas generales, y sustituyendo las viejas butacas de madera por nuevas tapizadas, mucho más cómodas para los espectadores. Sería entonces cuando decidieron alquilar los dos coliseos a la empresa Barrueco, ofreciendo esta sesiones de cine durante algunos años ${ }^{52}$. Para entonces la crisis de la exhibición cinematográfica en Zamora se había consolidado debido al número de salas que se asentaron en la ciudad. De hecho, Eugenio Pérez Macías, a la sazón, regente del Cinema Valderrey, explicaba que, para una ciudad como Zamora, seis cines —en esa época- era un auténtico despropósito ${ }^{53}$.

Tras ofrecer proyecciones durante alguna temporada, los hijos de Sanvicente decidirían, a mediados de los setenta, volver a traspasar el coliseo. Esta vez la empresa fue la Financiera de Espectáculos, S.L. —regente del Cine Arias Gonzalo_-, la cual agotaría su contrato a comienzos de los años ochenta.

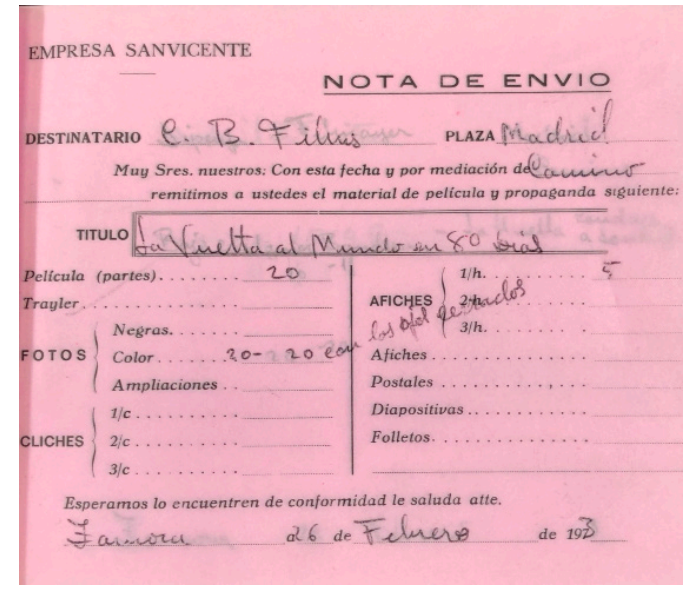

Figura 8. Nota de envío de una película del Teatro a la distribuidora. Fuente: A.H.P.Za. A.M.Za. Propios y Arbitrios. L-2-197

49 Este coliseo pasaría a denominarse Teatro Ramos Carrión, en honor al dramaturgo zamorano. El Correo de Zamora, 30-VII-1949, p.4.

50 El Correo de Zamora, 18-III-1987, p.6 y 8-XI-1956, p.2.

51 El Correo de Zamora, 21-XI-1967, p.8.

52 Tras cumplir su contrato con los hermanos Sanvicente, Ángel Barrueco compraría el local del Cinema Valderrey para reconvertirlo en Cine Pompeya en 1971. El Correo de Zamora, 26-VIII-1988, p.8.

53 El Correo de Zamora, 1-I-1963, p.4. 


\section{La decadencia del coliseo}

El 31 de marzo de 1984 se bajaría definitivamente el telón del Teatro Principal para las exhibiciones cinematográficas con la película Lili Marleen (R. W. Fassbinder, 1981). A través de una nota de prensa, la familia Sanvicente — que había poseído en propiedad el coliseo durante casi sesenta años-, se despediría del público zamorano:

Esta noche, cuando finalice la última sesión, el TEATRO PRINCIPAL de Zamora, bajará definitivamente el telón de su explotación comercial... Se cierra una larga etapa de trabajo, de entrega al público, con aciertos y errores, éxitos y fracasos. Solo pedimos comprensión con la labor que hicimos; en ella pusimos todo nuestro corazón. Al público que durante este tiempo nos ha acompañado igracias! Gracias y hasta siempre ${ }^{54}$.

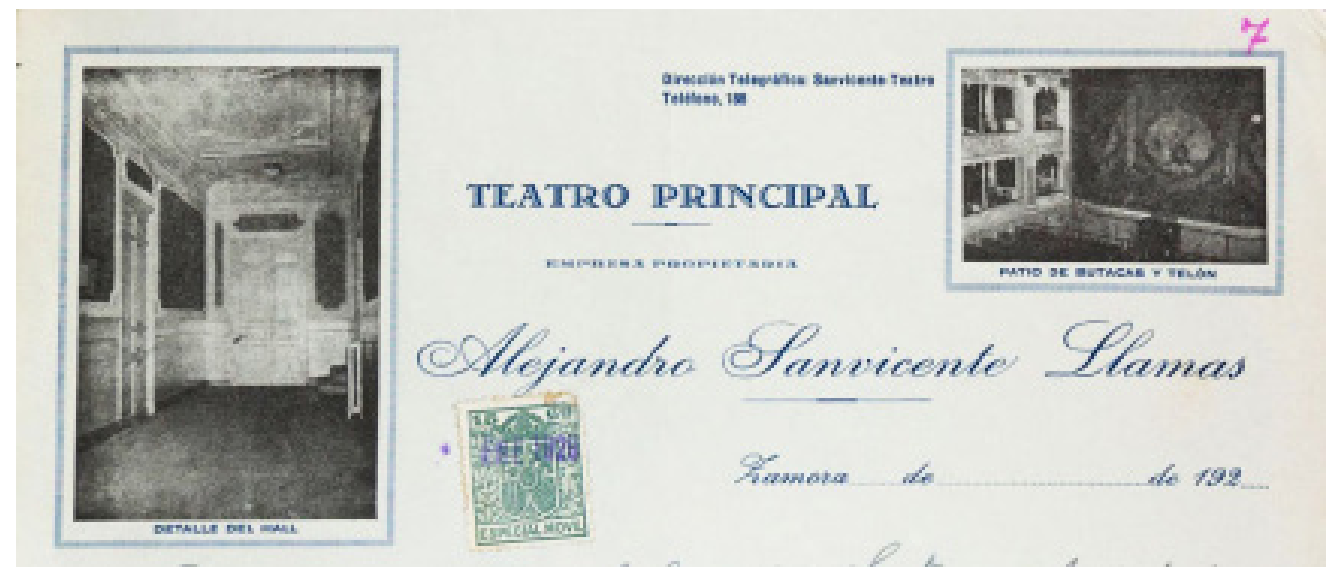

Figura 9. Membrete de una hoja de contratación de la empresa del Teatro Principal. Fuente: A.H.P.Za. Hacienda, fondo antiguo. Administración de Rentas. 902A.

La crisis del sector era una crónica de una muerte anunciada. De hecho, Ángel Barrueco, dueño y empresario de los cines Barrueco y Pompeya, vaticinaba unos meses antes, el escaso porcentaje de asistencia del público a las salas de la capital:

La situación en Zamora es igual a la del resto del mundo. Desde febrero (de 1983) para acá la afluencia de público ha bajado en un 70 por ciento debido fundamentalmente, a la fuerte competencia del vídeo que permite a todo el mundo tener el cine en su propia casa. La crisis del cine está provocada además del vídeo, por un exceso de material extranjero que perjudica a las películas españolas ${ }^{55}$.

El coliseo fue adquirido por el Ayuntamiento con un coste de sesenta y cinco millones de pesetas, rehabilitándolo en 1988 para convertirlo en Teatro Municipal. La muerte del Principal, también es la etapa más cruenta de la crisis de exhibición 
cinematográfica en la capital. Durante ese 1983 la cifra de espectadores a las salas había bajado alarmantemente. De hecho, en el Cine Barrueco se suspendería una sesión de la película El rey de la comedia (The King of Comedy, Martin Scorcese, 1982) porque el ínfimo número de espectadores ${ }^{56}$, a los cuales se les devolvió el dinero de la entrada ${ }^{57}$. Debido a ello, se acordó - por parte de todos los empresarios de cine - establecer el día del espectador para intentar aliviar la situación. Pero esta iniciativa no resultó eficaz, y la televisión generalista y de pago, así como el vídeo, establecieron la puntilla para la desaparición del cine — como espectáculos de masas — en la capital.

La evidencia más palpable de este abandono del espectáculo cinematográfico son los continuos cierres de las grandes salas en el centro de todas las ciudades y capitales. Esta práctica ha llevado a que lugares míticos de la historia del cine español se encuentren abandonados (Deltell \& García Fernández, 2013: 207).

\section{Conclusiones}

Esta investigación arroja algunas conclusiones sobre la exhibición cinematográfica en el Teatro Principal de Zamora durante el pasado siglo. La crisis del sector comenzaría con la llegada de la competencia - seis cines - a mediados de la centuria. Durante los años sesenta y setenta, la crisis se acentuaría con la llegada de la televisión y posteriormente del vídeo.

A la clausura del Teatro durante los años ochenta le siguieron escalonadamente el resto de cines de la capital, llegando a rebajarse esta cifra a tan solo dos cines en $1992^{58}$.

Se puede observar cómo la crisis de la exhibición vino provocada por dos causas. La primera fueron los altos porcentajes por cada cinta que imponían las distribuidoras a los empresarios de cine, llegando hasta el setenta por ciento. La segunda, tiene que ver más con el carácter social del propio cine. Durante los setenta, con la llegada de la televisión y demás medios de ocio, el cinema quedó relegado a posiciones, no tan primigenias, lo que provocaría su paulatina baja demanda.

Su cierre es un claro ejemplo del inicio de la crisis cinematográfica a nivel nacional, ya que hasta diez años más tarde, esta depresión no se vería reflejada en localidades más pobladas. Incluso en Madrid y Barcelona esta situación se produciría veinte años después del cierre del Teatro Principal (Deltell y García Fernández, 2013: 207).

Como se observa en el trabajo, este coliseo fue la sala más destacada de exhibición cinematográfica en Zamora durante la pasada centuria. Comenzó ofreciendo sesiones durante la etapa finisecular del siglo XIX, para más tarde afianzarse como la sala más innovadora de la capital. Con esta investigación se ha querido realizar una visión panorámica de lo que en su día fue lugar de encuentro social de los vecinos de la ciudad.

56 Tan solo cinco.

57 El Correo de Zamora, 30-XII-1983, p.30.

58 Llegándose a datos similares de principios de siglo xx, donde Zamora contaba con dos salas 


\section{Bibliografía}

Ávila de la Torre, A. (2009). Arquitectura y urbanismo en Zamora (1850-1950). Zamora, España: IEZ Florián de Ocampo, Diputación de Zamora.

Casquero, J. A. (2008). La Guerra Civil en Zamora: imágenes de la vida cotidiana en una ciudad de la retaguardia. Zamora, España: Centro de la UNED en Zamora.

Castrillón \& Martín. (1997). El espectáculo cinematográfico en Valladolid (1920-1932). Valladolid, España: Junta de Castilla y León y SEMINCI.

Cebrián, R. (2006) Zamora, Prisión Provincial, 1936. En Blanco Rodríguez (Coord.). A los 70 años de la Guerra Civil. Actas del encuentro celebrado en Zamora. Zamora, España: UNED Centro de Zamora.

Deltell, L. \& García Fernández, E. C. (2013). La promoción fílmica en el universo digital. Hacia el ocaso de la exhibición cinematográfica en España. Historia y Comunicación Social. Vol.18 No Especial Noviembre. Págs. 203-217.

Díez Puertas, E. (2003). Historia social del cine en España. Madrid, España. Fundamentos.

Fernández Colorado, L. (2002). El "phonofilm”: un sistema ambulante de cine sonoro. Alicante, España: Biblioteca Virtual Miguel de Cervantes, http://www.cervantesvirtual. com/nd/ark:/59851/bmcw9563

Fernández Duro, C. (1883). Apuntes de historia del teatro en Zamora. En Heraldo de Zamora, 21-I-1928, p.2.

Gubern, R. (1986). 1936-1939, la guerra de España en la pantalla: de la propaganda a la historia. Madrid, España: Filmoteca Española.

Herrero, M. A. (2006) Arquitectura zamorana del siglo XX: Antonio García Sánchez-Blanco (1893-1963). (Tesis doctoral). Salamanca, España: Universidad de Salamanca.

Madrid, J.C. (2009). 8.000 películas de cine primitivo. Gijón (Asturias), España: Centro de Iniciativas Culturales.

Martínez, A. (2017). El hombre que trajo el cine sonoro a España. En Las batallitas del cine español. Madrid, España: Cadena Ser. Recuperado de: http://cadenaser.com/ programa/2017/06/03/sucedio_una_noche/1496484929_734480.html

Méndez Leite, F. (Padre). (1965). Historia del cine español. Tomo I. Madrid, España: Ediciones Rialp.

Montes, S. (2017). Saturnino Ulargui y la distribución cinematográfica en el contexto de la II República Española. Tesis Doctoral. Salamanca, España: Universidad de Salamanca.

(2016). El papel de las distribuidoras cinematográficas en el desarrollo del cine español durante la II República. En Revista Arte y Patrimonio, Núm.1. Asociación para la Investigación de la Historia del Arte y del Patrimonio Cultural "Hurtado Izquierdo". Montilla (Córdoba), España.

Palacio, M. (2010). Los salones cinematográficos españoles. El camino que llevó a la Gran Vía. En Lahoz, J.I. (Coord.). A propósito de Cuesta. Escritos sobre los comienzos del cine español. 1896-1920. Valencia, España: Ediciones de La Filmoteca (Institut Valencià de l'Audiovisual i la Cinematografia).

Ruiz, L.E. (1997). Obras maestras del cine mudo. Época dorada (1918-1930). Bilbao (Vizcaya), España: Mensajero.

Sánchez-Biosca \& Tranche. (1993). NO-DO: El tiempo y la memoria. En Cuadernos de la Filmoteca. Núm. 1. (p.21). Madrid, España: Filmoteca Española. Instituto de la Cinematografía y de las Artes Audiovisuales.

Ventura, C. M. (1988). Historia del teatro en Zamora. Zamora, España: Fundación Ramos de Castro para el estudio y promoción del hombre. 


\section{Archivos}

Archivo General de la Administración (Alcalá de Henares, Madrid).

Archivo Histórico Provincial de Zamora (A.H.P.Za.).

Archivo Municipal de Zamora (A.M.Za.).

Anuarios Cinematográficos (Filmoteca Nacional de España).

Biblioteca de la Facultad de Ciencias de la Información (Universidad Complutense de Madrid).

Fototeca de la Filmoteca de Castilla y León (Salamanca).

Hemeroteca de El Correo de Zamora. Biblioteca Pública del Estado (Zamora).

Hemeroteca del Heraldo de Zamora. Biblioteca Virtual de Prensa Histórica. Web del Ministerio de Educación, Cultura y Deporte.

\section{Agradecimientos}

A Luis Deltell Escolar, profesor de la Facultad de Ciencias de la Información. A José-Andrés Casquero Fernández, archivero e historiador del Archivo Histórico Provincial de Zamora.

A los funcionarios de la Biblioteca Pública del Estado y del Archivo Histórico Provincial de Zamora.

Al departamento de Ciencias de la Comunicación Aplicada y a la Biblioteca de la Facultad de Ciencias de la Información de la Universidad Complutense de Madrid. 